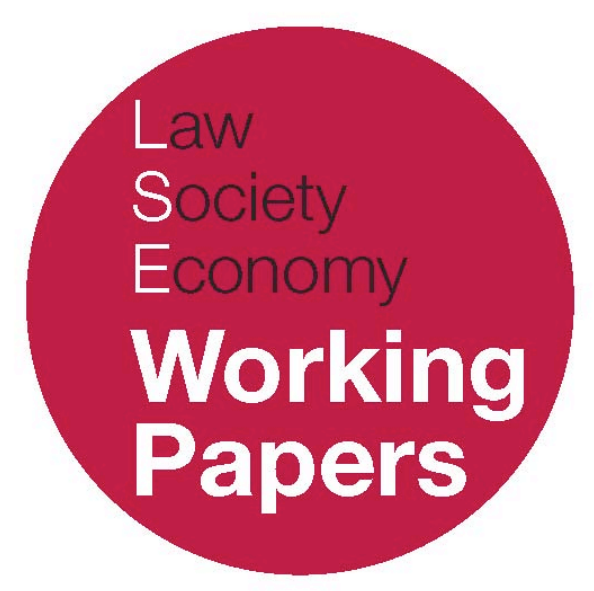

\title{
The Evolution of Competition Law and Policy
}

\author{
in the United Kingdom
}

\author{
Andrew Scott \\ LSE Law, Society and Economy Working Papers 9/2009 \\ London School of Economics and Political Science \\ Law Department
}

This paper can be downloaded without charge from LSE Law, Society and Economy Working Papers at: www.lse.ac.uk/collections/law/wps/wps.htm and the Social Sciences Research Network electronic library at: http://ssrn.com/abstract $=1344807$.

(C) Andrew Scott. Users may download and/or print one copy to facilitate their private study or for non-commercial research. Users may not engage in further distribution of this material or use it for any profit-making activities or any other form of commercial gain. 


\title{
The Evolution of Competition Law and Policy in the United Kingdom
}

\author{
Andrew Scott ${ }^{*}$
}

\begin{abstract}
A modern, statutory competition regime emerged in Britain only after the Second World War, developing somewhat haphazardly thereafter. From today's vantage, this policy was tentative, partial, and under-enforced. Only by the passing of the Competition Act 1998 and the Enterprise Act 2002 did the United Kingdom achieve a regulatory scheme that evinces a coherent design and an orthodox underpinning rationale. The relative tardiness of this development is a perplexing fact. For decades, the UK had been a primary exponent of the neoliberal philosophy that places faith in markets as the most efficient means of allocating societal resources. Yet the introduction of the necessary corollary - an effective policy designed to police newly competitive markets - did not emerge until recent years. This paper, first, notes the pertinent common law in this regard and outlines chronologically the main statutory competition measures introduced in the UK in the fifty years following the Second World War. Secondly, it considers the curious period of inaction in the face of an evident need to revisit competition policy at the end of the C20th. Thirdly, it offers a brief overview of the design of the systems introduced under the Competition Act 1998 and the Enterprise Act 2002, and interrogates the motivations behind such reforms. Finally, it reviews the underpinning purposes and the design of the more minor developments that have occurred since 2003. Ultimately, the intention is to allow some insight into factors which explain how and why UK competition law developed - or conversely, failed to do so - over recent legal history.
\end{abstract}

\section{INTRODUCTION}

Defined broadly, competition law has occupied a place in the corpus of English law for many centuries. While it elsewhere provided a foundation for the emergence of antitrust policy, however, the doctrine of the restraint of trade remained in Britain only a residual limitation on the freedom of commercial

* Law Department, London School of Economics and Political Science. 
operators. Modern statutory competition policy first emerged in the aftermath of the Second World War, but even then the progenitors of such early emanations no doubt mindful of the proven benefits of monopoly and cartelisation during times of crisis - were no free-market ideologues. In consequence, from today's vantage the laws that they introduced were tentative, partial, and under-enforced. Indeed, it was only in 2000 with the coming into force of the Competition Act 1998, and 2002 with the passage of the Enterprise Act that the United Kingdom saw the completion of a rounded scheme of law. This scheme evinces the promotion of competition and economic efficiency, now the orthodox position in international terms, as its key underpinning rationale. ${ }^{1}$

That the United Kingdom has only relatively recently introduced a coherent competition regime is a perplexing fact. Since the advent of the government of Prime Minister Margaret Thatcher in 1979, the United Kingdom has been a primary exponent of the neoliberal philosophy that places faith in markets as the most efficient means of allocating societal resources. ${ }^{2}$ Privatisation, liberalisation, deregulation, and the 'contracting out' of public competences all quickly became mainstays of British economic policy. Yet the introduction of the necessary corollary - an effective policy designed to police newly competitive markets - did not transpire for almost two decades. Certainly, an important mitigating factor was the influence of EC competition law which ensured that the anti-competitive agreements and practices of the very largest corporate entities - those whose behaviours might impinge upon trade between Member States of the European Community - were potentially supervised. The supranational policy, however, could not compensate in full for the absence of a domestic counterpart.

If perplexing, the tardiness of the United Kingdom in introducing effective competition policy is now largely of historic interest only. In 1998 in respect of anti-competitive agreements and the control of abuse of dominance and in 2002 in respect of merger control, the British government through Parliament determinedly redressed the balance. It offered restatements of the objectives of competition policy, reformed and invigorated institutional competences and procedural frameworks, and revised the legislative provisions under which competition investigation and enforcement proceeds. In its short modern history, the new UK competition regime has already proven itself an exemplary system. ${ }^{3}$ While further revisions have since been instigated these have been of second

\footnotetext{
${ }^{1}$ Formally, the United Kingdom of Great Britain and Northern Ireland comprises three distinct legal jurisdictions: England and Wales, Scotland, and Northern Ireland. Statutory competition law is applicable across all three jurisdictions, whereas common law rules were justiciable only in England and Wales (with the Northern Irish courts developing a sui generis, albeit parallel version).

2 While recent Labour governments have dallied with the concept of 'The Third Way', their aspiration to promote social justice has been underpinned by implicit faith in markets.

3 In a peer review undertaken by consultants KPMG in 2007, the UK regime ranked third behind those of the US and Germany - KPMG, Peer Review of Competition Policy (London: DTI, 2007) (available at: [WWW] http://www.berr.gov.uk/files/file39863.pdf (accessed May 2008)). In 2006, the Global Competition Review ranked the UK Competition Commission joint first among regulators alongside the US DoJ and FTC.
} 
order; they have been introduced to improve performance with regard to purposes previously set, rather than to effect further fundamental change.

The paragraphs that follow, first, note the pertinence of the common law and outline chronologically the main statutory competition law measures introduced in the UK in the fifty years following the Second World War. The second focus is the curious period of inaction in the face of an evident need to revisit competition policy alongside the wider shift in the direction of neoliberal economic policy at the end of the Twentieth Century. This section also includes a brief overview of the design of the system introduced under the Competition Act 1998. Thirdly, the advent of the new merger regime in 2003 is considered, the basic structure of the regime outlined and the motivations for change in this context interrogated. Fourthly, the underpinning purposes and design of the more minor developments that have emerged since 2003 are briefly reviewed. Ultimately, the intent is to allow some insight into factors which explain why UK competition law developed - or conversely, failed to do so - over recent legal history. ${ }^{4}$

\section{THE GRADUAL EVOLUTION OF PRE-MODERN COMPETITION POLICY IN THE UK}

Notwithstanding the existence of a latent, embryonic antitrust law in the shape of the doctrine of the restraint of trade, historically United Kingdom courts and legislators were slow to recognise and respond to the need to police the activities of significant commercial enterprises. ${ }^{5}$ In some measure this tardiness can be attributed to an over-weaned and persistent Victorian commitment to the politics of laissez-faire when British enterprises enjoyed an international pre-eminence, and then to a growing perception of the apparent value of unrestrained monopoly, conglomeration and cartelisation in the face of changed conditions of international trade. The upshot was that neither the common law nor statute provided for the emergence of a juridical system of antitrust familiar in other major jurisdictions before the outbreak of World War II.

\footnotetext{
${ }^{4}$ For more developed histories of UK competition law, upon which the following discussion draws heavily, see Wilks, In the Public Interest: Competition Policy and the Monopolies and Mergers Commission (Manchester: Manchester University Press, 1999); Gerber, Law and Competition in Twentieth Century Europe: Protecting Prometheus (Oxford: Oxford University Press, 2001) 207-227; Mercer, Constructing a Competitive Order: the Hidden History of British Anti-trust Policies (Cambridge: Cambridge University Press, 1995); Rowley, The British Monopolies Commission (London: Allen \& Unwin, 1996); Morgan, Monopolies, Mergers and Restrictive Trade Practices: UK Competition Policy 1948-1987 (Edinburgh: David Hume Institute, 1987); Stevens and Yamey, The Restrictive Practices Court: A Study of the Judicial Process and Economic Policy (London: Weidenfeld \& Nicolson, 1965).

5 A second common law doctrine, that of conspiracy to injure (which outlaws agreements between two or more competitors to injure a third party), might reasonably have been thought relevant to the discouragement of cartel behaviour. This possibility was undermined, however, by the courts' early taking of the view that a conspiracy was lawful if the primary object of the conspirators was to further their own interests: see Mogul Steamship Co. Ltd v McGregor Gow \& Co. [1892] AC 25; Crofter Hand Woven Harris Tweed Co. Ltd v Veitch [1942] AC 435.
} 
In contrast, from the mid-C20th onwards there was no shortage of legislative intervention in this domain. What this activism lacked, however, was any consistent sense of a coherent underpinning rationale. Competition policy has been based only to a limited extent on economic theory. ${ }^{6}$ Each reform, introduced spasmodically on a four or five year cycle, responded to immediate exigencies and focused on divergent aspects of competition policy:

the policies did not grow from a clear design or policy vision... [they] emerged incrementally and piecemeal as a result of consensus building by a powerful civil service, heavily influenced by business lobbying, increasingly responding to developments in economic thought, and operating under a benign and exceptional mantle of political bi-partisanship. ${ }^{7}$

The result was that by the mid-1990s it could fairly be stated that British competition law was in urgent need of a consistent and coherent underpinning. The central aim of this section is to outline briefly the purpose and content of the various post-war legislative interventions. The section begins, however, with a note on the common law origins of - or perhaps the dissolving backdrop to - UK competition law.

\section{ORIGINS OR IRRELEVANCIES: THE COMMON LAW DOCTRINE OF THE RESTRAINT OF TRADE}

The doctrine of restraint of trade is of early vintage in English law, with Dyer's Case (1414) often identified as a founding precedent. ${ }^{8}$ It has provided the base for an attempt by courts to reconcile the freedom to trade with the freedom to contract. ${ }^{9}$ The doctrine holds that contractual limitations on parties' wider behaviour are prima facie void unless justified as reasonable. A restraint is identified where the parties agree that one party will "restrict his liberty in the future to carry on trade with other persons not parties to the contract in such manner as he chooses". ${ }^{10}$ The concept of reasonableness introduces a public policy discretion, and is judged by reference to both the perceived interests of the parties concerned and the

\footnotetext{
${ }^{6}$ Liesner and Glynn, 'Does Antitrust Make Economic Sense?' (1987) 8(4) European Competition Law Review 344; Furse, 'The Role of Competition Policy: A Survey' (1996) 17(4) European Competition Law Review 250; Willimsky, 'The Concept(s) of Competition' (1997) 18(1) European Competition Law Review 54; Harbord, 'The Analysis of Barriers to Entry and Exit in United Kingdom Competition Policy' (1995) 16(5) European Competition Law Review 319.

7 Wilks, n 4 above, 25.

${ }^{8}$ See generally, Heydon, The Restraint of Trade Doctrine (London: Butterworths, 2nd ed, 1999); Trebilcock, The Common Law of Restraint of Trade: a Legal and Economics Analysis (Toronto: Carswell, 1986). Some authors cite a parallel focus of early legislation on monopolies in discussing the origins of British competition policy, including the Statute of Monopolies of 1624 which gave a remedy of triple damages and double legal costs to any person aggrieved by an unlawful monopoly - see, for example, Turner, 'The Need for an Effective Competition Policy' (1984) 6 European Intellectual Property Review 331.

9 AG of the Commonwealth of Australia v Adelaide SS Co [1913] AC 781, 795.

10 per Diplock LJ, Petrofina (Great Britain) Ltdv Martin [1966] Ch 146, 180.
} 
interests of the public. ${ }^{11}$ In the former respect, factors such as inequality of bargaining power or perceived unfairness to the restrained party have proved relevant to the assessment.

While it is often invoked as an underlying aspect of UK competition policy, the importance of the doctrine should not be overstated. Indeed, it has been argued that by the early Twentieth Century judicial constriction of the common law rules - attributed to a persistent commitment to the ideology of laissez-faire economics and the primacy of freedom of contract - had progressively "eviscerated their practical importance". ${ }^{2}$ Even were this not the case, recent legislative developments would have had an important bearing. In decentralising enforcement of EC competition law, Article 3 of EC Regulation 1/2003 provided a series of measures designed to ensure - to the extent possible - uniformity of application of EC competition law across the many Member States of the Union. This includes the injunction that national laws applicable to agreements that may have an effect on trade between Member States cannot be more strict than Article 81 EC..$^{13}$ The Regulation admits - exceptionally - that national laws that predominantly pursue an objective different from that of competition law may still be applied. ${ }^{14}$ The restraint of trade doctrine has been interpreted, however, as serving the same ends as competition law. In Days Medical Aids Ltd v Pibsiang Machinery Manufacturing Co Ltd, Langley J criticised the 'artificiality' of the common law doctrine before indicating that in terms of purpose it comprised "no more than earlier language for the restraint on competition at which Article 81 is aimed". 15

At least in the context of agreements governed by EC competition law, therefore, the public interest component of the common law rules has been deemed an ersatz economic efficiency criterion. The fundamental result is that the desire for uniform application has seen the common law rule to all intents and purposes expunged. ${ }^{16}$ One might expect that the application of the doctrine to 'domestic-only' agreements will be corralled by an extension of such logic as to purpose, and that this common law forebear of statutory competition law will lose any lingering relevance.

\footnotetext{
11 Nordenfelt $\mathrm{v}$ Maxim Nordenfelt Guns and Ammunition Co. Ltd [1894] AC 535; Mason v Provident Clothing \&o Supply Co [1913] AC 724. It should be note that the public interest in this context was rarely thought to be an important discrete category, but was generally considered to coincide with the interests of the parties.

12 Gerber, $n 4$ above, 208.

13 Council Regulation (EC) No 1/2003 of 16 December 2002 on the implementation of the rules on competition laid down in Articles 81 and 82 of the Treaty [2003] OJ L1/1, Article 3(2).

14 ibid Article 3(3).

15 [2004] EWHC 44 (Comm), para 254. Mr Justice Langley admitted that the conclusion may "come as something of a surprise to many practitioners" for its emphasis on the public policy aspect of the doctrine as opposed to the interests of the parties. For this reason, the judgment has been described by one commentator as "a remarkable recognition of the extent to which the doctrine has moved from being a matter of individual liberty and become one of economic regulation" - see Furse, Competition Lan of the EC and UK (Oxford: Oxford University Press, 4th ed, 2004) 369

16 Kammerling and Osman, Restrictive Covenants under Common and Competition Law (London: Sweet \& Maxwell, 4th ed, 2004) 289.
} 


\section{Baby Steps: Monopolies and Restrictive Practices (InQuiry and CONTROL) ACT 1948}

By the mid-Twentieth Century, therefore, there was little competition law to speak of in the United Kingdom. The first statutory intervention came in 1948, with the passing of the Monopolies and Restrictive Practices (Inquiry and Control) Act. This step forward can be best explained by reference to the wider reconstruction and social justice agenda of the period. One driving impetus of policy rolled out by the Labour Government in the aftermath of the Second World War was the desire to orient corporate power towards serving general social interests. A key aspiration was full employment. On the presumption that full employment would most likely be achieved under a competitive economy, discouraging anti-competitive behaviour was considered likely to contribute to the fulfilment of this objective.

The enthusiasm for the new law - which marked a decisive moment in the development of British competition policy - was politically bipartisan. Nevertheless, it was relatively cautious. The primary aim of the 1948 Act was to flesh out the intuition that monopoly and agreements - while profitable for the firms involved - were in some circumstances damaging to the wider public interest (viz workers and small businesses). The legislation provided only limited coercive machinery. The new regime could count either as a glass half-full or half-empty depending on perspective. Wilks explains further that:

the British vocabulary talked of 'monopolies' and 'restrictive practices' but it did not regard them as unlawful and was not 'anti' anything. Indeed, although nowadays these terms have become pejorative, the normative coloration was more muted... when both monopoly and restrictive practices had proved their worth. ${ }^{17}$

Under the Act, the Secretary of State was empowered to instigate investigations by the newly established Monopolies and Restrictive Practices Commission (MRPC) into goods industries in which it was thought that extant anti-competitive practices may be damaging to the 'public interest' (a concept that was non-exhaustively defined in section 14 of the Act). The threshold for investigation was that in excess of one third of supplies (or purchases) on the market must be made by one entity (or group of associated entities).

Thus, the 1948 Act begot British competition policy as an essentially administrative - as opposed to legal - beast. ${ }^{18}$ This approach has remained familiar into recent times. In the few years following the creation of the Commission, it investigated concerns in a range of markets, including the supply of dental goods, cast-iron rainwater goods, electric lamps, insulated electric wires and cables, insulin

\footnotetext{
17 Wilks, n 4 above, 24.

18 The scheme was enhanced by the Monopolies and Restrictive Practices Commission Act 1953 which strengthened the organisation of the Commission, and saw its capacity significantly enhanced.
} 
and imported timber. ${ }^{19}$ While noting that the legislative scheme was "timid" and the Commission's investigations largely educative only, Gerber emphasises that this role "should not... be underestimated, because it helped to change attitudes to competition". 20 Another author agrees forcibly that the Act caused a "psychological convulsion" across British industry on account of it censorious decrial of what had for many become standard practice. ${ }^{21}$

\section{A BipARtite ApProACH: THE RESTRICTIVE PRACTICES REgIME AND THE RETURN OF LEGALISM}

While on its own terms, the MRPC could be considered a success, it was not long before the impetus for further reform bore fruit. One driver of change was the attitude of many business leaders towards the discretionary system introduced by the 1948 Act. There was significant disquiet in such quarters regarding the perceived room for arbitrariness and political machination inherent in such regulatory design. Wilks lists the complaints:

the inquisitorial nature of the [Commission] investigations; the alleged lack of clarity of the case 'against' the company; the vagueness of the public interest test; the lack of a right to see third-party allegations or to reply to conclusions; the amount of money and senior management time required, and the unpredictability of the [government] response. ${ }^{22}$

There was a desire for a more juridical regime that it was supposed would at least offer business a greater degree of legal certainty. In something of an exercise in 'doublethink', it was expected that any legal regime would yet not constrain business freedom overmuch.

A second important factor was the extent to which broad swathes of the British economic system was infused with collusive behaviour. ${ }^{23}$ In this environment, a scheme that highlighted behaviours in only one industry at a time seemed to some like Canute's dyke. This limitation of the 1948 scheme was

\footnotetext{
${ }^{19}$ The text of each of these reports and the others undertaken are available on the webpages of the UK Competition Commission: [WWW] http://www.competition-commission.gov.uk/rep_pub/reports/ index.htm (accessed May 2008).

${ }^{20}$ Gerber, $\mathrm{n} 4$ above, 216. Similarly, Mercer characterises the Act as 'gentle' - see n 4 above, 102.

${ }^{21}$ Allen, The Structure of Industry in Britain (London: Longman, 2nd ed,1966) 70, cited in Wilks, n 4 above, 33.

22 Wilks, ibid 36.

23 Based upon data made available by the Registrar of Restrictive Trading Agreements, Elliott and Gribbin estimated that 54.1 per cent of output in 1958 manufacturing was subject to cartelisation, with some sectors being sufficiently more so - see "The Abolition of Cartels and Structural Change in the United Kingdom' in Jacquemin and de Jong (eds), Welfare Aspects of Industrial Markets (Leiden: Neijhoff, 1977) 345. Other research suggests that this overall figure is a reasonable point estimate, but subject to a wide margin of error. Broadberry and Crafts identified 35.7\% of 1958 market sectors as cartelised, a further $36.9 \%$ as having been subject to indeterminately successful attempts at cartelisation, and only $27.4 \%$ as essentially free from the influence of cartel agreements - see 'Competition and Innovation in 1950s Britain' (2000) LSE Economic History Working Paper Series, 57/00, 6-11 (available at: [WWW] http://www.lse.ac.uk/collections/economicHistory/workingPapers.htm (accessed May 2008)).
} 
highlighted by the MRPC itself in two ways. On one hand, its general activism saw business, policy makers, and the wider public become better educated as to the advantages of competition and the distortions often introduced by collective and monopolistic behaviour. The result was that appreciation of the scale of the problem promoted calls for further intervention. On the other hand, in 1955, it published a general report on the prevalence of collective discrimination in the form of agreements on exclusive dealing, collective boycotts, aggregated rebates and other discriminatory practices. ${ }^{24}$ This report contributed strongly to a widespread sense that l'heure bleu preceding the introduction of any more stringent responses to self-serving business practices was drawing to a close. In its conclusions, the majority of the Commission reported that the general effect of the types of agreements surveyed was to operate against the public interest. ${ }^{25}$ The majority considered that "the powers at present available to the Government in this field are insufficient to implement our conclusions", and that further legislation would be necessary. ${ }^{26}$

The majority of the Commission then went further than their terms of reference to moot two possible forms of action: a general, criminal prohibition on the restrictions considered (with provision made for limited exceptions), or a system of registration and subsequent assessment of individual restraints. The majority preferred the former alternative. A registration scheme would not pardon many agreements, but yet would be cumbersome, slow and unfair. ${ }^{27}$ Conversely, a general prohibition "would give industry clear and unequivocal guidance as to the Government's policy, and would avoid the uncertainty and waste involved in detailed inquiries in each individual case". ${ }^{28}$ While a general prohibition may seem drastic, it would be less far-reaching than provisions in comparative jurisdictions.

A minority of the Commission did not agree that the evidence and information presented during the investigation warranted a view that impugned forms of agreement should be thought presumptively injurious to the public interest. ${ }^{29}$ It considered that a general prohibition would therefore cause injustices, and would be inflexible in the face of changing economic circumstances. The minority would accept a registration system as discounted by their contemporaries, as they considered this would afford salutary publicity and allow a more focused assessment of particular agreements. The cleavage among the members of the Commission thus centred on what should be the default presumption regarding the different forms of collective discrimination from which exceptions would be permitted; whether such agreements should be considered prima facie problematic

\footnotetext{
${ }^{24}$ Monopolies and Restrictive Practices Commission, Collective Discrimination: A Report on Exclusive Dealing, Collective Boycotts, Aggregated Rebates and other Discriminatory Trade Practices. Cmnd 9504 (London: HMSO, 1955).

25 ibid, para 233. It allowed that there may be specific circumstances in which there would not be detriment to the public interest, and detailed these in paragraph 240.

26 ibid para 242.

27 ibid para 245.

28 ibid para 247.

${ }^{29}$ The minority view is elaborated at para 255 et seq.
} 
or benign. It was the minority viewpoint that would prove influential as Parliament turned to revise the competition regime further.

The Restrictive Trade Practices Act 1956 heralded the emergence of a bipartite system. It promised stronger treatment of restrictive practices, while leaving the coverage of monopoly as it had been under the 1948 legislation. ${ }^{30}$ Companies were obliged to register agreements that included designated forms of cooperation with the Registrar of Restrictive Trading Agreements. The working presumption was that registered agreements were contrary to the public interest and hence should be unlawful and non-enforceable. The Registrar was to seek confirmation of this before the judges of the Restrictive Practices Court (a High Court). Many agreements were dissolved or amended in advance of this step taking place. However, section 21 of the Act offered a series of heads - or 'gateways' - under which it was to be possible for firms to contend that their particular agreement in fact did not operate contrary to the public interest. Where such an argument could be made, it was for the Court to assess the balance between the harms and benefits. ${ }^{31}$ This basic scheme was extended to collective resale price maintenance agreements by the Resale Prices Act 1964, and to information agreements by the Restrictive Trade Practices Act 1968. Under the Fair Trading Act 1973, the Director General of Fair Trading (DGFT) took on the role allotted to the Registrar by the earlier legislation. The relevant law was consolidated in the Restrictive Trade Practices Act 1976.

Despite a strong reception and initial success, ${ }^{32}$ over time criticism of the restrictive practices regime burgeoned. ${ }^{33}$ While the precedent value of decisions was undeniable, disquiet in respect of application of the somewhat nebulous public interest concept heightened steadily. Initially, the business community expected the six gateways through which companies could demonstrate coherence with the public interest to be clearly and generously interpreted. They were not. ${ }^{34}$ This misplaced optimism helps explain why the registration of agreements was essentially universal at the outset. Latterly, the regime began to suffer the pathological consequence that cartelists learned not to expose themselves by registering their activities, but rather preferred to 'go underground' by masking the existence of agreements. In similar vein, the formalistic nature of the requirements the regime imposed saw companies design-out potential problems in the structuring of agreements. Despite this increasingly broad-based criticism, this

\footnotetext{
30 In light of this shift, the MRPC was renamed the Monopolies Commission, reduced in size, and - for a time at least - relegated to a minor position in the wider competition regime - see Wilks, $\mathrm{n} 4$ above, 38 .

31 Thus, the judiciary was "reluctantly returned to the field of restrictive practices agreements from which it had been painfully extricating itself for the previous sixty years" - Stevens and Yamey, n 4 above, 19.

32 Wilks notes that the 1956 Act was a "revolutionary piece of legislation, which effectively squeezed most former cartels out of the industrial economy" - see n 4 above, 31 .

33 See, for example, Editorial, ‘A New Competition Act for the United Kingdom' (1987) 8(4) European Competition Law Review 273; Gerber, $\mathrm{n} 4$ above, 219.

34 Wilks explains that, indeed quite unexpectedly, the Restrictive Practices Court "proceeded to bowl over restrictive agreements and to send shock waves through industry which transformed the cosy world of cartels and restrictive practices" - n 4 above, 37 .
} 
regime essentially remained in place in respect of restrictive practices until the overhaul of the regime that took place in the late 1990s.

\section{Consolidation ANd IMPRovement of MONOPOLy Provisions}

With the advent of the restrictive practices regime, monopoly controls under the 1948 Act became a very much less active component of the overall regime. The MRPC was renamed the Monopolies Commission (MC), reduced in size, and - for a time at least - relegated to a minor position in the wider competition regime. While in 1965 the MC took on the additional role of merger review and became the Monopolies and Mergers Commission (MMC), its impact remained light. In 1973, the Fair Trading Act imposed on the DGFT an obligation to monitor markets and to recommend reference to the Commission where it perceived monopoly problems. It also reduced the threshold for reference from 33 to $25 \%$ market share. Thus, while the 1973 Act radically revised the institutional structure of competition law, creating the DGFT and thereby providing a dedicated agency and spokesperson for competition policy, in the monopoly context power was left in the hands of political decision-makers. It was the Secretary of State who would decide on the recommendation of the DGFT whether to make a reference. The system was used sparingly, it was long-winded, ${ }^{35}$ and the advice offered by the Commission - while invariably thorough and impartial - was generally too factspecific to be of precedent value for firms seeking legal certainty. ${ }^{36}$

In 1978 and 1979, two Green Papers on competition law mooted reform that culminated in the introduction of a sui generis investigatory mechanism. ${ }^{37}$ The main innovation was reflected in the Competition Act 1980.38 This was motivated by the purported emphasis paced on competition by the incoming Thatcher Government and by the relative success of EEC law. It sought to overcome the problem that the practices and vertical agreements of monopolists could be investigated only under the cumbersome and lengthy monopoly procedure.

The Act introduced the concept of the 'anti-competitive practice', which allowed the Director General - and ultimately the Monopolies and Mergers Commission - to investigate particular practices of specified firms in a relatively streamlined form of inquiry. The emphasis was placed upon the effects of

\footnotetext{
35 Under this mechanism the Commission was obliged to investigate the operation of whole industry sectors rather than the behaviour of individual firms with market power.

36 Gerber, $\mathrm{n} 4$ above, 220-222.

${ }^{37}$ Department of Trade and Industry, $A$ Review of Monopolies and Mergers Policy: a consultative document. Cmnd 7198 (London: HMSO, 1978); A Review of Restrictive Trade Practices Policy. Cmnd 7512 (London: HMSO, 1979).

38 See Gerber, n 4 above, 222-225; Hutchings, 'The United Kingdom Competition Act 1980' (1980) 1 European Competition Law Review 81; Pickering, 'The Economics of Anti-Competitive Practices' (1982) 3 European Competition Law Review 253; Howe, 'The Competition Act: Early Case Law' (1982) 3 European Competition Law Review 331; Lever, 'United Kingdom Economic Regulation: Use and Abuse of the Law' (1992) 13(2) European Competition Law Review 55; Everton, 'Discrimination and Predation in the United Kingdom: Small Grocers and Small Bus Companies - A Decade of Domestic Competition Policy' (1993) 14(1) European Competition Law Review 6.
} 
behaviour, rather than industry structure or form of agreements. Where the DGFT perceived an anti-competitive effect of behaviour, he would then refer the matter on to the Commission, first for deeper assessment of the effect of the practice and secondly for benchmarking against a public interest test. There was an incentive for impugned firms to settle cases and desist with problematic behaviour in order to avoid a reference. Despite the apparent promise of this new component of the competition regime, however, it was seldom deployed. Writing in 1985, one commentator noted that "the use made of the new procedures so far has been unimpressive... most [cases] range from the minor to the trivial". 39

\section{The Advent And Development of Merger Control}

The competition aspects of mergers have been regulated formally in the United Kingdom since 1965 when the Monopolies and Mergers Act renamed and extended the jurisdiction of what was then the Monopolies Commission. ${ }^{40}$ The United Kingdom became only the second jurisdiction after the United States to possess a fully-fledged merger control regime. Notably, when the merger control regime was first introduced in 1965 it was merely grafted on to the pre-existing approach to monopoly control. ${ }^{41}$ The review of merger transactions was conducted by the MMC but ultimately determined by the Secretary of State by reference to a malleable conception of the 'public interest'. The basic principles laid down in 1965 were subsequently confirmed in the Fair Trading Act 1973, which also provided more adequate administrative machinery. The Director General of Fair Trading would henceforth advise the Secretary of State on decisions regarding reference to the Commission after undertaking a preliminary screen of unproblematic cases. This system proceeded to operate for almost three decades.

This arrangement allowed much room for the exercise of a fairly unconstrained political discretion. The public interest test was drawn from the Monopolies and Restrictive Practices (Inquiry and Control) Act 1948 in which it had not been tightly defined. Such guidance on interpretation of the phrase as the 1948 Act did offer was expressed at such a level of generality as to amount to an invitation to take into account anything that might seem relevant. ${ }^{42}$ In addition, the determinative aspects of the review process were to be administered by a

\footnotetext{
${ }^{39}$ Morgan, $\mathrm{n} 4$ above, 32-33.

40 It became the Monopolies and Mergers Commission. Prior to that time, the Government did possess informal means of influencing at least some mergers - see Ellis, 'A Survey of the Government Control of Mergers in the United Kingdom' (1971) 22 Northern Ireland Legal Quarterly 251 and 459, 277.

${ }^{41}$ The impetus for the introduction of merger controls had grown markedly in the early 1960s, not least in response to the ICI attempt to take over Courtaulds - see Editorial, 'No Policy for Mergers' (1962) 202 The Economist 393; Board of Trade, Monopolies, Mergers and Restrictive Practices. Cmnd 2299 (London: HMSO, 1964). See generally, Wilks, n 4 above, 195-204; Ellis, ibid 277-280; Goyder, 'Monopolies and Mergers Act' (1965) 29 Modern Law Review 693.

42 s 14. One commentator with an American pedigree considered that the British accommodation of wider goals was 'understandable' - although still easily criticised - given the absence of 'a long-established abhorrence of governmental intervention (as has prevailed in the United States) or a 'great fear of high economic concentration' - see Ellis, ibid 256.
} 
Government minister who was allowed a broad measure of executive discretion. This is perhaps unsurprising given that the regime emerged at a time when it was widely accepted that "industrial performance [could] be improved, not by more competition, but by promoting mergers that restructure and concentrate... industry into fewer and larger units". ${ }^{43}$ It is a fair assessment that the new regime reflected a strongly corporatist approach to government-industry relations, ${ }^{44}$ and that it seemed destined to achieve to "a low priority, low profile and low impact". 45

Hence, in its early years the regime was open to criticism for the inconsistency and apparent arbitrariness of decisions reached, and for political interference on non-economic grounds. ${ }^{46}$ The reference policy pursued by the Secretaries of State was described as at once "the most important and the most mysterious aspect of British merger control". ${ }^{47}$ While the Fair Trading Act 1973 refined the interpretative guidance offered on the meaning of the public interest by section 14 of the 1948 Act, this improved matters only marginally.48 In 1980, one commentator reviewed the experience under the public interest test, and categorised the reasoning of decisions under nine distinct headings of which the effect on competition was only one. ${ }^{49} \mathrm{~A}$ formalised expression of the sometime importance of non-competition factors was discernible in the 'Lilley doctrine'. ${ }^{50}$ As regards the exercise of the executive discretion, the record of ministers has been somewhat fickle. It has been asserted that there is "absolutely no doubt that some Secretaries of State have been 'softer' on merger control... [and] that legal practitioners have drawn the appropriate conclusions and advised their clients accordingly". ${ }^{51}$ From 1973 to the end of 2001, the various Secretaries of State had

\footnotetext{
43 ibid 274-277. Attitudes towards this 'national champions' policy has shifted markedly in the intervening time - see Geroski, 'Competition Policy and National Champions' (2005) Speech delivered to WIFO, Vienna, 8 March; Scott, 'Last Rites for the Two-Thirds Rule in EC Merger Control?' (2006) Journal of Business Law 619, 626 et seq.

44 Wilks, n 4 above, 199.

45 ibid 202.

46 See, for example, Rowley, 'Mergers and Public Policy in Great Britain' (1968) 11 Journal of Law and Economics 83; Sutherland, The Monopolies Commission in Action (Cambridge: Cambridge University Press, 1969). See also, a number of chapters in Fairburn and Kay (eds), Mergers and Merger Policy (Oxford: Oxford University Press, 1989).

${ }^{47}$ Ellis, n 40 above, 286

48 s.84 of the 1973 Act set out five considerations that should be borne in mind when applying the public interest test: maintaining and promoting effective competition; promoting the interests of consumers, purchasers and other users of products; encouraging the reduction in costs and new innovation; maintaining and promoting the balanced distribution of industry and employment, and promoting the competitiveness of national firms on international markets.

49 Pickering, 'The Implementation of British Competition Policy on Mergers' (1980) 1 European Competition Law Review 100.

50 This espoused that any proposed acquisition should be particularly closely scrutinised where the proposed purchaser was foreign (and especially if state-owned). It resulted in a number of references to the Commission in the early 1990s. Four of the five cases involved, however, were cleared by the Commission, while the fifth was prohibited on normal competition grounds. It was based upon a departmental circular - Department of Trade and Industry, Press release, 26 July 1990. See generally, Wilks, n 4 above, 226 .

51 ibid. This contention was supported by an analysis of the number of referrals made per year by successive Secretaries of State.
} 
acted contrary to advice received from the Director General of Fair Trading on 31 occasions. 52

Over time, however, the very malleability that saw merger control begin life as a secondary adjunct to corporatist industrial policy was exploited to redirect attention in an increasingly economics-oriented direction. The public interest benchmark was revised through practice to become more or less akin to a competition standard. In part this was a response to unremitting criticism, and in part to the underlying shift in the political environment towards market-based economics that accompanied the election of Mrs Thatcher's governments. While as a matter of form, the Fair Trading Act 1973 reiterated that the assessment of mergers should proceed against a conception of the public interest that comprised a range of considerations, the effect of a merger on competition became the preeminent aspect of the test. Therefore, at least to some extent, the reforms introduced by the Enterprise Act serve only to confirm the basis on which merger control has been conducted in practice over recent times. ${ }^{53}$

The "Tebbit guidelines" are often cited as the single most important staging post in the transition to a competition-based test. First outlined in a Parliamentary answer in 1984, the guidelines consist of the injunction that the eponymous Secretary of State's "policy has been and will continue to be to make references primarily on competition grounds". ${ }^{54}$ Similar statements were endorsed by many of Lord Tebbit's successors. Notably, however, the Tebbit guidelines were also pre-empted by statements made by some of his predecessors in post. 55 Thus, the 1984 statement should not be seen as a fixed fulcrum in time around which the behaviour of Secretaries of State swung towards a competition standard. Rather, it has become an exemplary moment; a touchstone of a wider progressive trend. Indeed, the idea of an exclusively competition-based test has some long provenance in the UK. Even before the introduction in 1965 of merger controls based on protection of the public interest, government officials had mooted such an option only to see it set aside at that point in time. ${ }^{56}$ After October 2000, the Labour Government pursued an explicit policy of compliance with the recommendations of the Office of Fair Trading (OFT) and Commission in all but exceptional circumstances. ${ }^{57}$ It followed this by allowing merger control an institutionalised independence in the Enterprise Act 2002.

\footnotetext{
52 ibid 226 (1973-1997), and 376 HCDeb col 944W, 13 December 2001 (1997-2001). See, for example, General Electric Co plc / VSEL plc, Cm 2852 (1995); National Power plc / Southern Electric plc, Cm 3230 (1996).

53 Goodman, 'Steady as She Goes: the Enterprise Act 2002 Charts a Familiar Course for UK Merger Control' (2003) 24(8) European Competition Law Review 331.

54 Department of Trade and Industry, Press release, 5 July 1984.

55 Wilks, $\mathrm{n} 4$ above, 222

56 ibid 197.

57 Department of Trade and Industry, 'Byers Announces Major Overhaul of Mergers System', Press release, 26 October 2000. Clearly, as noted in the discussion of the Lilley doctrine above, there were aberrations from the competition benchmark in the practice of Secretaries of State after the mid-1980s.
} 


\section{CONCLUSIONS}

The culmination of this thirty year post-war mix of occasional new thinking coupled with incremental reform was a system that was widely disparaged and not well-understood. At a general level, Wilks has explained that

the complexity and ambiguity of British competition agencies and law, as they stood in 1997 ahead of the Labour reforms... reflected peculiar policy dynamics. The policy did not grow from a clear design or a policy vision. They were not forged in a furnace of public outrage (as in the US); they were not imposed as part of the fruits of victory (as in Japan); neither were they conceived as part of a vision of political and economic integration (as with the EEC). Instead British policy emerged piecemeal and incrementally. ${ }^{58}$

Particular criticisms abounded, and included concerns that the system was extremely complicated, that it failed to provide competition agencies with sufficient investigative powers or sanctions, that it required the registration of relatively innocuous agreements placing unnecessary burdens on business and regulators and diverting attention away from uncovering illicit hard-core cartels, and that there was an unhelpful divergence from the sibling system of competition law developed by the EEC. In short, few were content with the status quo.

\section{THE LATE EMERGENCE OF AN EFFECTIVE ANTITRUST POLICY}

From today's vantage British competition policy seems both stable and coherent. It is easy to forget the relatively recent history of discord and concern. Yet for perhaps twenty years prior to the 1998 reforms there was a burgeoning exasperation with the state of competition laws in the United Kingdom and the apparent disinterest of government, notwithstanding false dawns, in addressing widely perceived problems. The following paragraphs review the curious period of inaction during the lengthy period of Conservative party governance from 1979, before outlining the changes that were instigated by the newly elected Labour successor in 1998.

\section{'SCREAMING AT THE UMPIRE': THE PROLONGED AND CURIOUS INACTION ON ANTITRUST}

Over time, the home-grown understandings of the limitations of the British administrative approach to restrictive agreements and behaviours developed under post-War legislation were confirmed by the increasingly significant counterpoint

58 Wilks, n 4 above, 173. 
offered by the development of EC competition law. Following the accession of the UK to the European Economic Community in 1973, Articles 85 and 86 EEC (now Articles 81 and $82 \mathrm{EC}$ ) became applicable to business dealings that had an effect on trade between Member States of the European project. In effect, this covered much of the activity of larger firms. The EC scheme for controlling anticompetitive compacts (under Article $81 \mathrm{EC}$ ) focused on the effects of agreements. In contrast, the UK restrictive practices regime was concerned with the form of the agreement. In particular, the UK law fetishised the formal terms of agreements and sought to confirm whether they were phrased in the form of restrictions as opposed to obligations. It was possible for the 1976 Act to apply in its full rigour to agreements which had little or no impact upon competition. ${ }^{59}$ At the same time, agreements that were plainly anticompetitive in both object and effect could lie outside the regulatory ambit. This was not a simple case of the exemplary nature of one regime reflecting badly on the poor performance of another. Rather, the two bodies of law imposed different and potentially dichotomous regulatory burdens even - conceivably - on the same companies in respects of the same practices. This ensured that the situation was unsustainable.

The need for reform was recognised in government, but significant action was not immediately forthcoming. The two Green Papers on competition law reported in 1978 and 1979 culminated in the Competition Act 1980 which did not revise the restrictive practices or monopoly control regimes but rather introduced a third strand to British antitrust policy. ${ }^{60}$ After ten years of relative inaction, the Conservative Government published a further Green Paper. ${ }^{61}$ This document accepted the need for fundamental alteration in the law of restrictive practices, and proposed the approximation of the UK control of anti-competitive agreements to Article 81 EC. A White Paper published the following year confirmed this intention, and also offered a précis of the perceived weaknesses of the extant regime. ${ }^{62}$ It was acknowledged that "our present system is inflexible and slow, too often concerned with cases which are obviously harmless and not directed sufficiently at anti-competitive agreements". ${ }^{63}$ It was proposed, amongst other things, to create a more powerful competition authority to take over the powers of the Director General; to abolish the registration system under the 1976 Act and replace it with an Article 81(1) EC style general prohibition, and to implement a system of individual and block exemptions modelled on Article 81(3) EC. These

\footnotetext{
59 This outcome was narrowly avoided by the House of Lords in MD Foods Plc Formerly Associated Dairies Ltd) v Baines [1997] 1 All ER 833.

60 Department of Trade and Industry (1978), n 37 above; (1979) n 37 above. On this 'third strand', see above text accompanying $\mathrm{n} 38$.

61 Department of Trade and Industry, Review of Restrictive Trade Practices Policy. Cm. 311 (London: HMSO, 1988). See Eccles, 'Transposing EEC Competition Law into United Kingdom Restrictive Trading Agreements Legislation: Commentary on the United Kingdom Government's Green Paper' (1988) 9(2) European Competition Law Review 227.

62 Department of Trade and Industry, Opening Markets. Cm 727. (London: HMSO, 1989). See Editorial, 'Proposals for New UK Restrictive Practices Law: Commentary on the United Kingdom Government's White Paper Opening Markets' (1999) 10(4) European Competition Law Review 469.

63 ibid para 2.8.
} 
proposals were originally expected to be implemented by 1991, but were shelved in the light of self-serving and arguably duplicitous complaints from industry that well-understood principles would be replaced by a regime based on uncertainty.

In 1992, a further Green Paper outlined an alternative series of possible reforms. ${ }^{64}$ This time, the focus was putative reform of the law on the abuse of monopoly. The options considered were to strengthen the existing structure under the Fair Trading Act 1973; to introduce a general prohibition on abuse of dominant position, following Article $82 \mathrm{EC}$, or to adopt a dual system which retained the Fair Trading Act 1973 and introduced the prohibition on abuse of dominant position alongside it. Responses to the consultation were varied and inconsistent. The Government determined to strengthen existing law, and the radical, 'harmonising' option was foregone. While the Green Paper reaffirmed the government's intention to legislate as soon as time permitted, ultimately not even this lesser degree of action ensued. Instead the Deregulation and Contracting Out Act 1994 restricted the ambit of United Kingdom competition law without attempting to bring it into line with the Treaty of Rome. ${ }^{65}$

The breaking point for the competition policy epistemological community was reached in 1995. The platform was a House of Commons Select Committee inquiry into extant monopoly controls. The evidence-taking sessions for this inquiry were described in The Economist as "one long stream of rage... [in which] those testifying before the committee... unleashed a barrage of criticism at the country's competition laws and regulatory bodies". ${ }^{66}$ The Committee itself reported that the Government's excuses were "wearing thin". ${ }^{67}$ It recommended the adoption of a prohibition approach based substantially on Article $82 \mathrm{EC}$, and the reform of the institutional structure so as to establish a unitary authority. The Government's response was recalcitrant, indicating that no significant reform of monopoly control would be forthcoming. ${ }^{6}$

The Government did come forth with further proposals in respect of restrictive practices law in 1996, again mooting substantive and institutional alignment with EC law. ${ }^{69}$ It rejected the idea that there should be a generalised

${ }^{64}$ Department of Trade and Industry, Abuse of Market Power. Cm 2100 (London: HMSO, 1992). See Taylor, 'Abuse of Market Power: The Green Paper Proposals' (1993) 14(4) European Competition Law Review 169-172.

${ }^{65}$ Pratt, 'Changes in United Kingdom Competition Laws: A Wasted Opportunity' (1994) 15(2) European Competition Law Review 89.

66 Anon, 'Screaming at the Umpire' (1995) The Economist, 1 April.

${ }^{67}$ Trade and Industry Committee, Fifth Report: UK Policy on Monopolies (1994-95) HC 249-1. See Hutchings, 'The Need for Reform of United Kingdom Competition Policy' (1995) 16(4) European Competition Law Review 211; Rodger, 'Decentralisation, the Public Interest and the 'Pursuit of Certainty': reform of UK competition policy - the Trade and Industry Committee Report' (1995) 16(7) European Competition Law Review 395.

${ }^{68}$ Department of Trade and Industry, Government Observations on the Fifth Report from the Trade and Industry Committee (Session 1994-95) on UK Policy on Monopolies (1995) HC 748.

${ }^{69}$ Department of Trade and Industry, Tackling Cartels and the Abuse of Power (London: HMSO, 1996). See Furse, 'The Role of EC Law in United Kingdom Reform Proposals' (1996) 17(2) European Competition Law Review, 134; Robertson, 'The Reform of United Kingdom Competition Law - Again?' (1996) 17(4) European Competition Law Review 210; Rose, 'Tackling Cartels: The Green Paper Proposal for Implementing the Government's Policy on Restrictive Trade Practices' (1996) 17(7) European Competition Law Review 384. 
prohibition on abuse of a dominant position, and instead recommended the strengthening of the monopoly investigation procedures under the Fair Trading Act 1973. Publication of a draft Bill suggested that progress was imminent, but the failure to include the legislation in the Queen's Speech - which opens Parliament and outlines the Government's legislative programme for the coming year suggested further prevarication. In May 1997, the Conservative Government lost office for the first time in eighteen years.

Within weeks of the Labour party coming into office in 1997, a new Competition Bill was published. This was wide-ranging in its objectives. It provided for the transposition of something very much like both Articles 81 and 82 EC into United Kingdom law, introducing general prohibitions of anticompetitive agreements and abuse of a dominant position. ${ }^{70}$ The Competition Act 1998 received the Royal Assent in November 1998, and was brought into full force in March 2000.71 A new era of competition oversight and enforcement had begun.

\section{A Time to Dance?: The Competition Act 1998}

The central objective of the Competition Act 1998 was to align national competition law as closely as possible with EC law (Articles 81 and 82 EC), and thereby to reduce the regulatory burden on companies. This was achieved through the introduction of the 'Chapter I' and 'Chapter II' prohibitions on anticompetitive agreements and abuse of a dominant position respectively. These provisions provided almost verbatim reproductions of the EC equivalents, subject to the necessary jurisdictional revisions. In the normal case, the new prohibitions are enforced by the Office of Fair Trading (OFT). ${ }^{72}$ In industry sectors covered by sectoral regulators, however, the Competition Act also introduced concurrent enforcement powers for the respective sectoral regulators. ${ }^{73}$

\footnotetext{
${ }^{70}$ Scholes et al, 'The United Kingdom Draft Competition Bill: Comments Based on Observations of the Competition Law Association' (1998) 19(1) European Competition Law Review 32; Barr, 'Has the United Kingdom Gone European: Is the European Approach of the Competition Bill More Than an Illusion?' (1998) 19(3) European Competition Law Review 139; Peretz, 'Detection and Deterrence of Secret Cartels Under the United Kingdom Competition Bill' (1998) 19(3) European Competition Law Review 145.

71 Maitland-Walker, 'The New United Kingdom Competition Law Regime' (1999) 20(2) European Competition Law Review 51; Nazerali and Cowan, 'Importing the EU Model into United Kingdom Competition Law: A Blueprint for Reform or a Step into 'Euroblivion'?' (1999) 20(2) European Competition Law Review 55; Editorial, 'A Blueprint for Reform: Response by the Office of Fair Trading' (1999) 20(6) European Competition Law Review 309.

72 In formal terms, the OFT as a body corporate replaced the personalised DGFT as the enforcement agent. Formerly, the OFT had existed by was in effect merely the label ascribed to the collection of officials operating under the auspices of the Director General.

73 s 54 and Sch 10, Competition Act 1998. The sectors and regulators in question are: Office of Communications (Ofcom) - media and communications; Gas and Electricity Markets Authority (Ofgem) and Northern Ireland Authority for Energy Regulation (Ofreg NI) - gas and electricity markets; Office of Water Services (Ofwat) - water and sewerage; Office of Rail Regulation (ORR) - railways, and the Civil Aviation Authority (CAA) - air traffic. Regulations govern the relationship between the regulators with respect to their concurrent powers - see The Competition Act 1998 (Concurrency) Regulations 2004 SI2004/1077. In addition a Concurrency Working Party has been established comprising representatives
} 
This reform was not 'harmonisation' wrought by EC law. There was no suggestion that the EC had become sovereign in the area of domestic competition law. The British Government chose unilaterally through Parliament to revise the law and to introduce a number of mechanisms designed to ensure continuing confluence of the two distinct bodies of law - domestic and European - over time. It was not obliged to do so. This was a pragmatic realignment designed to improve the law and in particular to reduce regulatory burdens on British business.

Section 2 of the 1998 Act contained the equivalent prohibition to Article 81(1) EC. Section 3 then excluded certain types of agreement - such as mergers, which remained subject to the Fair Trading Act 1973 - while section 50 provided for the ad hoc exclusion of vertical agreements and land agreements. In a mirror image of the EC notification regime current at that time, section 4 provided for the granting by the Office of Fair Trading of 'individual exemptions' from the prohibition where conditions set out in section 9 (equivalent to Article 81(3) EC) were satisfied by the agreements in question. Sections 6-8 provided for the issuing by the Secretary of State of British 'block exemptions' in respect of categories of agreement. The introduction of this scheme saw the repeal of the erstwhile restrictive practices regime.

Section 18 of the 1998 Act contained the Chapter II prohibition on abuse of a dominant position, the UK equivalent to Article 82 EC. This general prohibition repealed and replaced the anti-competitive practices provisions of the Competition Act 1980. However, the Fair Trading Act 1973 powers to investigate structural monopolies by means of a market investigation were initially retained, although they were subsequently superseded by equivalent provisions in the Enterprise Act 2002.

Given that the central aim of the Competition Act 1998 was to parallel as closely as possible the competition law developed under Articles 81 and 82 EC, the 1998 legislation provided mechanisms to sustain coherence over time. The first novel feature was the provision made for 'parallel exemption' from the application of the Chapter I prohibition. Section 10 of the Act explained that where an agreement either does or would benefit from a block exemption issued by the Commission if it affected trade between member States, then such exemption will also prevail against the Chapter I prohibition. This ensured a lighter burden for business (which would not face differing rules in regard of specific types of agreement) and for the OFT (which would not therefore need to prepare legislation with regard to types of agreement already covered by European regulations). Secondly, section 60 of the Act consisted of a 'governing principles clause'. This provided that so far as was possible (having regard to any relevant differences between the provisions concerned) any questions of UK competition law were to be determined as would the equivalent questions under EC law. Subject to the 'relevant differences' caveat, judgments of the European courts and

of each regulator in order to facilitate a consistent approach in the exercise of their respective functions and powers. 
principles of the Treaty were drawn in as binding sources of law, while decisions and statements of the European Commission were to be taken into account by domestic decision-makers. ${ }^{74}$

Under the Competition Act 1998, the OFT and sectoral regulators are allotted wide investigatory powers which include the power to enter premises and to conduct searches, and to seize documents and other items. The falsification, destruction and failure to provide information are all made criminal offences. The authorities may impose interim measures to avoid competition harm during an inquiry. Should they then find an infringement of one or other prohibition, they can give directions requiring it to be brought to an end. Such a finding may also attract a fine of up to ten per cent of turnover subject to a three year limit. Decisions of the OFT or sectoral regulators can be appealed to the Competition Appeal Tribunal, and from there on to the Court of Appeal. ${ }^{75}$

\section{CONCLUSIONS}

British competition policy moved into a new era of prospective stability in the late 1990s, one in which policy seemed finally to match the undergirding philosophy. It is tempting to see the move to emulate European competition law in the domestic frame as an essentially pragmatic shift. This would be to lose sight of the fact that by that time EC law had itself almost fully endorsed the basic commitment to market - as opposed to planned - solutions to resource allocation questions, and to the promotion of competition between efficient market participants as the goal of policy.

It remains difficult to discern the reasons for the prolonged inaction on the part of successive governments until that point, especially given the strength of the ideological faith in markets manifested in governmental policy more generally. It may have been that the Conservative governments from 1979 simply considered that they had larger fish to fry: the need to rationalise and marketise the provision of public services, and the drive first to privatise publicly-owned industries and then in some cases to regulate to achieve ersatz competitive market outcomes. There is also the suspicion that by dint of the scale of its engagement with business - its aspiration to understand and replicate its modes of operating - those earlier governments may have become too beholden to business interests. Government may have been captured by the agenda of business, and so failed properly to recognise that where this verged towards seeking protection from competitive forces or towards discounting the exploitation of market power it did not necessarily correlate with the interests of the country at large.

\footnotetext{
${ }^{74}$ Goodman, 'The Competition Act, Section 60: The Governing Principles Clause' (1999) 20(6) European Competition Law Review 314; Willis, 'Procedural Nuggets from the 'Klondike Clause': The Application of Section 60 of the Competition Act 1998 to the Procedures of the OFT' (1999) 20(6) European Competition Law Review 314.

75 ss 46-49, Competition Act 1998.
} 


\section{EXTRICATING POLITICAL INFLUENCE FROM MERGER CONTROL}

In addition to the Competition Act reforms, June 2003 saw the transition to a new merger regime in the United Kingdom as the substantive provisions of the Enterprise Act 2002 came into force. ${ }^{76}$ This revision was motivated by an amalgam of three objectives: first, the extrication of political influence from the process of merger control. Secondly, the instigation of procedural reform to leave the regime more open and transparent, and thirdly, the installation of an exclusively competition-based standard against which mergers would henceforth be assessed. These principles, and the means by which they might best be pursued, were subject to much consultation and some revision in the years preceding their enactment. ${ }^{77}$

The culmination of this process is a system that resembles its forebear, but which has been enhanced in a number of respects. Qualifying mergers are identified by reference to quantitative criteria based on turnover and/or the share of supply of affected markets. The old assets test has been jettisoned as inadequate to the task of identifying mergers that may give rise to competition problems. In all but exceptional circumstances, it is for the OFT to refer qualifying mergers on to the Competition Commission (the renamed MMC) should it believe, after assessment against a competition-based test, that the merger is potentially problematic. It is then for the Competition Commission to investigate the matter in more depth and to determine whether action need be taken to remedy competition harms. It is only where a merger impinges upon specific public interest considerations that these determinative functions may move from the independent competition authorities to the Secretary of State for Business, Enterprise and Regulatory Reform. ${ }^{78}$ The Competition Appeal Tribunal performs a judicial review function in respect of substantive merger decisions. ${ }^{79}$ This is a

76 The Enterprise Act 2002 (Commencement No.3, Transitional and Transitory Provisions and Savings) Order 2003, SI 2003/1397. On the Enterprise Act regime generally, see Scott, Hviid and Lyons, Merger Control in the United Kingdom (Oxford: Oxford University Press, 2006).

77 The development of the proposals can be traced through a number of government documents - see Department of Trade and Industry, Mergers: A Consultation Document on Proposals for Reform. URN 99/1028 (London: DTI, 1999); Mergers: The Response to the Consultation on Proposals for Reform. URN 00/805 (London: DTI, 2000); Productivity and Enterprise: A World Class Competition Regime. Cm 5233 (London: The Stationery Office, 2001); Productivity and Enterprise - A World Class Competition Regime': Government's Response to Consultation (London: DTI, 2001).

${ }^{78}$ In 2002, the only stipulated public interest consideration related to the protection of national security.

${ }^{79} \mathrm{~s} 120$, Enterprise Act 2002. Interestingly, in the first judicial review case that came to the Competition Appeal Tribunal under the new regime, the Tribunal contended that "a particular feature of the specific context of section 120 is that Parliament has created the Tribunal as a specialised tribunal... in contrast to the more normal situation where a non-specialised court is called upon to review the decision of a specialised decision maker" - see IBA Health Limited v Office of Fair Trading [2003] CAT 27, para 220. The inference drawn by the OFT was that the Tribunal considered itself able to exercise a more interventionist jurisdiction than would normally be appropriate in the Administrative Court (which permits decisions to be impugned only in case of illegality, procedural impropriety or irrationality (the last being a very high hurdle before interference on the merits of decisions would be permissible). This would limit the freedom of the OFT to determine merger control outcomes at the first stage, and so it appealed the decision. In its judgment, the Court of Appeal reaffirmed the status quo: "if and in so far as [the 
most unusual administrative arrangement: a reference is made from one specialist body to another specialist body, with decisions taken being subject to review by a further specialist tribunal. ${ }^{80}$

It is interesting that the UK merger control regime remains relatively uninfluenced, at least in formal terms, by the parallel system of control established at the EC tier of governance in 1990. As regards substantive law, harmonisation is not pressing in this context as any given merger will be subject either to the United Kingdom or to the EC regime and not to both. The jurisdictions are exclusive. On the procedural side, while the EC regime provides for compulsory prior notification and the suspension of progress towards completion of notified mergers, the UK regime still allows for mergers to be considered ex post should the parties be willing to risk a subsequent prohibition and uncoupling. In addition, the UK has retained the involvement of two independent competition authorities in the assessment process, while the Directorate-General for Competition remains the sole arbiter of legality at the supranational level. ${ }^{81}$ As a matter of substance, however, it is clear that the two regimes will continue to inform one another greatly. This process can be expected to deepen with the involvement of both authorities in the European Competition Network. ${ }^{82}$

Since the 1960s, then, the merger control process in the United Kingdom has been shaped by commitment to two goals: competition and pragmatism. ${ }^{83}$ While the first of these has become increasingly dominant, the second helps explain deviations from that standard. In some respects, the Enterprise Act reforms see the final confirmation of the centrality of the competition standard. It is difficult to contend that the reforms do not involve the elimination of "a layer of political risk from the investigation process". ${ }^{84}$ In restricting the role of the Secretary of State to exceptional cases, the reforms limit the "substantial room for the exercise of political preferences" previously allowed. 85 The pragmatic tendency remains alive, however, in the retention of the public interest test for limited categories of merger transaction. ${ }^{86}$

Tribunal] did not apply the ordinary principles of judicial review... on the ground that [it] is a specialist tribunal or otherwise then they failed to observe the mandatory requirements of s 120(4)" - see: Office of Fair Trading and others v IBA Health Ltd [2004] EWCA Civ 142, para 53.

${ }^{80}$ In IBA Health, the CAT professed that "we cannot immediately think of a similar situation elsewhere in the legal system" (ibid para 59).

${ }^{81}$ In formal terms, the decision after the second phase assessment at the EC level is taken by the College of Commissioners - see generally, Navarro et al, Merger Control in the European Union: Law, Economics and Practice (Oxford: Oxford University Press, 2nd edn, 2005).

82 Arguably, the cross-fertilisation can be seen in the revisions made to the legal test in the EC Merger Regulation, and more tacitly in the guidance on the substantive assessment published by each authority.

83 Wilks adds the third tenet of 'permissiveness', and notes that an emphasis on general favourability towards mergers 'echoes down the decades' - see n 4 above, 205.

84 Allen \& Overy, Response to the Competition White Paper, 9 October 2001, para 4.

85 Wilks, n 4 above, 228.

86 On opening the consultation that led to the 2002 reforms, Peter Mandelsohn MP explained that where "there are aspects of the public interest the public is going to expect their interests to be represented by someone who is elected" - see Financial Times, 30 November 1998. 


\section{LATTER-DAY IMPROVEMENTS IN THE COMPETITION DOMAIN}

While it seems likely that the 'big bang' reforms of 1998 and 2002 will shape the overall structure of UK competition law for some years to come, there have nonetheless been numerous lower order amendments in the few short years since their introduction. Much of this further change has been prompted by changes at the EC tier of governance, and reflects a general desire to maintain coherence with that parallel regime. Other changes have been designed to augment the operation of the basic regime.

\section{Changes Motivated by ReCEnt EC REForm}

A range of refinements of UK competition law have been motivated by amendment to the parallel scheme of EC competition law and the desire to retain coherence therewith. A primary driver of change was the process of procedural improvement and 'decentralisation' or 'modernisation' initiated in Brussels. At around the same time as the Competition Act 1998 was adopted, the European Commission instigated a review of its own substantive competition laws and enforcement processes. The result of the European deliberations was Council Regulation 1/2003.87 Among other things, this abolished the notification regime under which companies had - falteringly - been able to obtain from DG Competition exemption for agreements under Article 81(3) EC. The new Regulation also transferred to Member States a more developed responsibility for dealing with infringements of EU competition law.

In light of the impending EC reforms, several changes were initiated in the UK to sustain the alignment of UK with EC law. For instance, with effect from May 2004, the UK scheme for the notification and possible exemption of agreements from the application of the Chapter I prohibition has been withdrawn. A legal exception regime now applies domestically as it does with regard to the supranational body of law. The ability to notify details of behaviour that might fall foul of the Chapter II prohibition has also been withdrawn. Similarly, powers available to the OFT to undertake investigation of domestic competition concerns were extended explicitly to permit equivalent approaches to behaviour covered by EC law. Moreover, as Regulation 1/2003 provided a formal basis for the acceptance by the Commission of commitments in lieu of a full scale investigation and decisions on putatively anti-competitive practices, domestic law was amended to allow the same facility with respect to domestic investigations under both EC and UK law.

Further reforms have affected the approach adopted towards vertical restraints. When the Competition Act 1998 first came into force, vertical agreements were excluded from the purview of the Chapter I prohibition by the

87 Council Regulation (EC) No 1/2003 on the implementation of the rules on competition laid down in Articles 81 and 82 of the Treaty. [2003] OJ L1/1. 
operation of an order made by the Secretary of State under section 50.88 This exclusion order was introduced on the understanding that the relevant EC law was somewhat under-developed and could not simply be followed, and that in any event the case for regulating vertical agreements was not conclusive. The European Commission has reviewed its approach to such agreements as part of a more wide-ranging infusion of economic literacy into EC competition law, and introduced a new-style Vertical Agreements Block Exemption. ${ }^{89}$ In consequence, the UK government removed the exclusion order in its application to vertical agreements. The result is that domestic competition law and (by virtue of section 10 of the 1998 Act) the parallel vertical block exemption will now apply to vertical agreements that do not have an effect on trade between member states. ${ }^{90}$ The OFT also indicated that it would revise its approach to the de minimus rules in this context, and that in future in considering this issue it will have regard to the Commission's Notice on Agreements of Minor Importance. ${ }^{91}$

\section{STAND Alone IMProvements to DOMESTIC CoMPETITION LAW}

A number of refinements to the regime confirmed by the Competition Act 1998 and the Enterprise Act 2002 have been introduced quite independently of EC influence. Three are worthy of particular note: the introduction of a 'cartel offence'; the part-reiteration and part-extension of special rules for 'media mergers', and the lifting of the threat of merger control from transactions involving 'small' markets.

Alongside its revision of the merger control regime, the Enterprise Act 2002 also served as the legislative vehicle for the introduction of criminal sanctions for cartel creation in the United Kingdom. Cartels are often described as the 'supreme evil of antitrust', as 'cancers on society', and as 'subtle but serious theft'. Whether or not these descriptions are apt, the use of competition laws against cartels has become the primary enforcement goal of competition authorities around the world. Even after the introduction by the 1998 Act of an applicable anti-cartel law in the Chapter I prohibition, of effective investigatory powers, and of deterring sanctions, however, a lingering enforcement problem was perceived. This was the potential for disjunction between the incentives of the company and the incentives of the company executives. The latter protagonists may not suffer personally by the time a cartel discovered, while their financial incentives may often encourage desire for high levels of profit. The essential purpose underpinning the 'criminalisation' policy device is the alignment of the incentives of individual executives with those of their employer-companies, ensuring the deterrence of

\footnotetext{
88 The Competition Act 1998 (Land and Vertical Agreements Exclusion) Order 2000 SI 2000/310. The exclusion did not apply to vertical agreements that had as their direct or indirect object or effect of restricting a buyer's ability to determine its subsequent selling price.

89 Commission Regulation (EC) No 2790/1999 on the application of Article 81(3) of the Treaty to categories of vertical agreements and concerted practices. [1999] OJ L336/21.

90 The Competition Act 1998 (Land Agreements Exclusion and Revocation) Order 2004 SI 2004/1260.

91 (2001) OJ C368/13.
} 
both from instigating and perpetuating cartel membership. Section 188 of the 2002 Act set out the criminal offence committed by those who dishonestly engage in a horizontal cartel agreement. The associated maximum sentence is five years imprisonment and/or an unlimited fine. Impugned directors can also suffer disqualification for a maximum period of 15 years..$^{92}$

A second notable reform motivated by domestic - albeit on this occasion extrinsic - policy concerns related to the introduction of special provisions for media mergers in the Communications Act 2003. The Act repealed the erstwhile regime for newspaper mergers, formerly prescribed by sections 57-62 of the Fair Trading Act 1973 and left in place by the 2002 Act. ${ }^{93}$ All media mergers are now generally considered under the standard merger provisions of the Enterprise Act 2002. The exception arises where the Secretary of State issues an intervention notice' instigating a review of the impugned merger against both competition rules and a set of "media public interest considerations". ${ }^{44}$ In this scenario, the merger control regime effectively reverts to the system under the Fair Trading Act with the OFT (and Ofcom) advising the Secretary of State on whether to refer the case to the Competition Commission, and the Commission advising on whether remedies are necessary to address perceived problems following a substantive investigation. Broadly, the need for assessment against media public interest considerations was introduced - by means of an amendment in the House of Lords during legislative debate - in order to prevent the debasement through merger of the quality and range of public expression within the public sphere. Thus, media cases have joined those involving national security as potential anomalies in the face of the presumption of political independence in British merger control.

Also in the merger context, the OFT has sought to reduce the burden of the merger control regime for companies that operate as large players in small markets: mergers where "the market concerned is not... of sufficient importance to justify the making of a reference to the [Competition] Commission". ${ }^{55}$ Such mergers are excepted from the merger regime. As a rough guide to this exception, the OFT originally indicated a market value of $f 400,000$, this being the approximate cost of a Competition Commission investigation. The purpose of the exception was said to be pragmatic. It was intended to prevent any investigation where the cost of the administrative burden of assessment would likely outstrip the value of the entire market concerned. The scheme was revised in November 2007, when the OFT published new guidance on this de minimis exception after a

92 s 204, 2002 Act

93 s 373 .

$94 \mathrm{~s} \mathrm{58,2002}$ Act. The first - and as yet the only - case to be referred to the Competition Commission by the Secretary of State under the revised powers was that involving the purchase by BSkyB of a $17.9 \%$ shareholding in ITV plc. The Competition Commission advised the Secretary of State - on competition grounds only - that the shareholding should be reduced to a maximum of $7.5 \%$ if the transaction was to be cleared. The Secretary of State agreed, but the case was subsequently appealed to the Competition Appeal Tribunal from which judgment is pending.

95 ss 22(2)(a) and 33(2)(a), Enterprise Act 2002. 
public consultation. ${ }^{96}$ The exception remains pragmatic, but it is to be operated on a proportionate - as opposed to direct equivalence - basis as between the costs and likely benefits of intervention. The new threshold for a market to be considered to be of sufficient importance has been set at $f_{10}$ million. In December 2007, the OFT utilised the de minimus exception for the first time in clearing two rail franchise mergers. ${ }^{97}$

\section{CONCLUSIONS}

It would appear from the short history of reform since the modernisation of British competition law and policy around the turn of the century, that British competition policy is unlikely to become reified, but rather will continue to be revised pragmatically in accordance with developing policy goals. These may be engendered by supranational reforms, perceptions of underperformance, or to entirely extrinsic policy aspirations. Any changes however will almost certainly be incremental only. The Competition Act 1998 and Enterprise Act 2002 will provide the bedrock of competition policy in the UK in perpetuity.

\section{CONCLUSIONS: FACTORS UNDERPINNING THE 'STOP-START' EVOLUTION OF UK COMPETITION LAW}

The foregoing paragraphs have outlined the stages in the development of British competition law and policy, essentially over a fifty year period. The purpose has been to tease out factors that have influenced the evolution of this corpus, both at various historical moments and in general. At this general level, it can be said that the key determinant of an effective policy is the ideological commitment to the value of open markets regulated to ensure the absence of development and exploitation of market power. In the United Kingdom, this commitment has some vintage. In terms of the coherence of policy and the suitability of institutions, however, it is only recently that a root and branch assessment has been undertaken and reform embraced. This was made much less risky by the existence of, and broad familiarity, with the EC competition law touchstone.

One potential risk to the economic and philosophical coherence of British competition policy in future concerns management of the interface with wider political aspirations, be they cultural, environmental, mercantile, or otherwise in nature. It may be that the pendulum may soon swing back towards market protectionism and intervention taking a range of forms. It is arguable that the

\footnotetext{
96 OFT, Revision to Mergers: substantive assessment guidance (Exception to the duty to refer: markets of insufficient importance) (2007) OFT 516b.

97 Arriva plc / Arriva Trains Cross Country Limited / Cross Country passenger rail franchise, 20 December 2007; National Express Group plc / Inter City East Coast rail franchise, 20 December 2007. Each of these cases involved affected markets valued at around $f_{1}$ million.
} 
reforms introduced into merger law in service of media policy have already had this effect, and that mercantilist aspirations grouped under the 'national champions' policy may soon do so. The risk is that such incursions may cloud the clarity of purpose of the competition law corpus. This may be more or less politically acceptable. The task of those who hold the coherence of competition policy precious is to ensure that if and when such dilutions are accepted and do occur, the justifications therefore must be explicit and persuasive. One strength of British competition policy today is that both the institutional design and the normative clarity of the law will require this to be the case. 